\title{
Effects of Slaughter Age and Season on Certain Carcass Characteristics in Holstein-Friesian Cull Cows
}

\author{
๑ Sena ARDICLI
}

Bursa Uludag University, Faculty of Veterinary Medicine, Department of Genetics, 16059, Bursa, Turkey

Received 19.05.2019 Accepted 04.10.2019

\begin{abstract}
The objective of this study was to quantify the effects of the factors including age at slaughter and slaughter season on certain carcass characteristics in cull cows. Data from 159 Holstein-Friesian cull cows were used and the cows were divided into three age groups including, very young ( $<2$ years), young (2-3years) and mature ( $>3$ years). Statistical analysis was carried out by the least-squares method as applied in a general linear model (GLM). Results indicated that mature cull cows were characterised by higher live weight, carcass weights, and bone content, whereas, young cull cows were characterised by higher carcass dressing values. In addition, autumn was significantly associated with higher live weight, bone content percentage, and processing loss, whereas, summer was associated with higher carcass dressings and chilling loss. No significant differences were observed in values of total meat yield and percentage and yields of valuable cuttings. The present results may be useful for the evaluation of factors influencing the decision to cull dairy cows.
\end{abstract}

Key words: Cull cow, retail cuts, carcass value, age at culling, environmental factors

\section{Introduction}

The sale of cull cows contributes to the overall profit of dairy herds and is one of the most important sources of meat production in Europe countries. ${ }^{1}$ In general, culled cows are sold directly for salvage values and the turnover represents a revenue source for dairy farms. The optimum culling rate exhibits an important economic property in terms of farm profitability, such that it has been suggested to be between $25 \%$ and $30 \%{ }^{2,3}$ However, culling rates have gradually increased because of multiple problems in dairy cattle management.

The common reasons for culling are reproductive failure, low milk production, mastitis and udder problems, and old age. ${ }^{2,4,5}$ While many factors are likely to contribute to the decision to cull dairy cows, as mentioned above, studies indicate reproductive failure as the primary reason for culling. ${ }^{5-7}$

The decision to cull is a complex one. ${ }^{2}$ Factors influencing the decision to cull dairy cows can be divided in two categories: the first one comprises cow factors, such as age and lactation rank, health status, milk production, reproductive performance, and disposition. The second comprises economic factors, including milk and carcass price, the price and availability of replacement heifers, and the farmer's attitudes. ${ }^{2,5,8}$

Holstein-Friesian breed is accepted as a significant premier dairy breed, and in addition, this breed is predominant among cattle breeds in Turkey. Accordingly, Holstein cull cows and the bulls are important sources for red meat 
production. It is obvious that, the main source of red meat is the cattle with the population of 17042506 in Turkey. In 2018, 1118695 tons of red meat was produced, and of this production, 1003859 tons (89.73\%) were composed of beef. ${ }^{9}$ The demand for red meat has gradually increased with the population growth rate and the economic dynamics. This situation has also led to a necessity to efficient databases and the detailed studies on beef production.

The characteristics of cull cow carcasses are expected to be highly variable with respect to their excessive heterogeneity in age and body condition. ${ }^{1}$ It seems that, at present, there is a need for studies on assessment of carcass traits and further-processing characteristics in culled dairy cows. Although cull cow carcasses have a significant impact on meat production, the relevant studies are quite limited in the literature. Taken altogether, the aim of this study was to determine carcass characteristics of Holstein-Friesian cull cows marketed in South Marmara Region of Turkey and to investigate the effects of slaughter age and season on final weight, carcass traits and further-processing characteristics.

\section{Materials And Methods}

\section{Data collection}

Data from a total of 159 carcasses from purebred Holstein-Friesian cull cows was used in the present study. No animal care and use committee approval is required for this work because experiments were conducted on only marketed cattle carcasses. All animals originated from a commercial farm, located in the South Marmara region of Turkey (Balikesir province), with the same feeding practices and management systems and they were recorded for the Turkish Ministry of Food, Agriculture, and Livestock Pedigree Project and Cattle Breeders Association. Cows were housed in free-stall barns and milked thrice daily. Only data with relevant records of slaughter weight and carcass traits were used in subsequent analyses. Variables of live weight and carcass traits were recorded during two seasons (summer and autumn). Maximum and minimum ambient air temperatures $\left({ }^{\circ} \mathrm{C}\right)$ in the slaughterhouse were $32.5 \pm 1.9$ and $17.8 \pm 0.9$ in summer and $17.1 \pm 1.4$ and $6.08 \pm 1.7$ in autumn and relative humidity percentages (\%)

Table 1. Number of cows by slaughter season and age group were $72.5 \pm 0.2$ and $60.7 \pm 2.4$ in the same seasons, respectively. For this particular analysis the animals were divided in three age groups according to their chronological age at the time of slaughter as follows: very young ( $<2$ years), young (2-3 years), and mature ( $>3$ years) (Table 1$)$. Prior to slaughter, live weight of each cow was recorded. All cattle were slaughtered in a commercial slaughterhouse of Bursa Province of Turkey. The duration of transport from farm to slaughterhouse was approximately $1 \mathrm{~h}$. All animals were slaughtered in compliance with the current national regulations applied in slaughterhouses. Carcass dressing followed a standardised protocol without removing the subcutaneous fat cover and keeping the kidney and pelvic fat. Hot carcass weight was taken approximately $1 \mathrm{~h}$ post-mortem. Carcasses were split into two sides with tail on the right side of the carcass and chilled at $4{ }^{\circ} \mathrm{C}$ for $24 \mathrm{~h}$ in a ventilated room. Thus, cold carcass weight and chilling loss were determined. The dressing percentage was calculated based on both hot and cold carcass weights, as (hot carcass weight or cold carcass weight / live weight $) \times 100$.

Carcasses quartered at the 12th/13th rib, bodies of the thoracic vertebrae were removed by sawing to the point where they joined the spinous processes and ribs. The sirloin tip was removed by cutting across the anterior end of the muscle in a line with the anterior edge of the aitch bone, whereas, the strip loin was separated from the round on a line between the aitch bone and the posterior end of the 5th sacral vertebra. ${ }^{10}$ Each retail cut was weighed on precision scale (100 g sensitivity) and weights of valuable cuts were determined. Bone content, total meat yield, and valuable cuts were determined and their proportions (\%), including bone content percentage, meat (boneless) percentage, and percentage of valuable cuts were calculated on the basis of cold carcass weight. Valuable cuts included rib, roast, sirloin, cutlet, striploin. Processing loss was calculated based on the boneless meat yield and expressed as the percentage of meat weight loss in further-processing.

\section{Data analyses}

Collected data were analysed using Minitab statistical package (MINITAB, Pennsylvania, USA, version: 17.1.0). Analysis of variance (ANOVA) was performed, and main factors (age and slaughter season), as well as their inter-

\begin{tabular}{lcccc}
\hline \multirow{2}{*}{ Slaughter season } & \multicolumn{3}{c}{ Age Groups } & \multirow{2}{*}{ Total } \\
\cline { 2 - 4 } & $\begin{array}{c}\text { Very young } \\
(<2 \text { years })\end{array}$ & $\begin{array}{c}\text { Young } \\
(2-3 \text { years })\end{array}$ & $\begin{array}{c}\text { Mature } \\
(>3 \text { years })\end{array}$ & \\
\hline Summer & 31 & 39 & 36 & 106 \\
Autumn & 20 & 16 & 17 & 53 \\
Total & 51 & 55 & 53 & 159 \\
\hline
\end{tabular}


actions (age $\times$ season), were studied by means of the least squares method, using the general linear model (GLM) procedure, and accepting differences between variables if $\mathrm{P}<0.05$. The following model was selected to analyse live weight and carcass traits:

$$
\mathrm{Y}_{\mathrm{ijkl}}=\mu+\mathrm{S}_{\mathrm{i}}+\mathrm{A}_{\mathrm{j}}+\mathrm{I}_{\mathrm{k}}+\mathrm{e}_{\mathrm{ijkl}}
$$

where: $Y_{i j k l}$ represents the studied traits, $\mu$ is the overall mean, $S_{i}$ is the fixed effect of slaughter season ( $i=$ summer and autumn), $A_{j}$ is the fixed effect of age group $(j=1,2$, and $3), I_{k}$ is the fixed effect of the age $\times$ season interaction, and $\mathrm{e}_{\mathrm{ijkl}}$ is random error.

In order to analyse total meat yield and valuable cuts, cold carcass weight was added to the above-mentioned model as a covariate, as follows:

$$
\mathrm{Y}_{\mathrm{ijklm}}=\mu+\mathrm{S}_{\mathrm{i}}+\mathrm{A}_{\mathrm{j}}+\mathrm{I}_{\mathrm{k}}+\beta \mathrm{C}_{1}+\mathrm{e}_{\mathrm{ijklm}}
$$

where: $Y_{i j k l m}$ represents the studied traits, $\mu$ is the overall mean, $S_{i}$ is the fixed effect of slaughter season $(i=$ summer and autumn), $A_{j}$ is the fixed effect of age group $(j=1,2$, and $3), I_{k}$ is the fixed effect of the age $\times$ season interaction, $\beta C_{1}$ is the regression effect of cold carcass weight, and $e_{i \mathrm{jklm}}$ is random error.

Two-way interaction of age $\times$ season was statistically non-significant $(\mathrm{P}>0.05)$ and hence was excluded from subsequent statistical analyses. In the case of significant differences, means were compared using the Tukey's test.

\section{Results And Discussion}

Least square means and analysis of variance are given for the effects of slaughter age on live weight and carcass traits in Table 2. As expected, highly significant differences among age groups were observed in live weight $(\mathrm{P}<0.001)$, hot carcass weight $(\mathrm{P}<0.001)$, hot carcass dressing $(\mathrm{P}<0.01)$, cold carcass weight $(\mathrm{P}<0.001)$, and cold carcass dressing $(\mathrm{P}<0.01)$. Results indicated that mature cows ( $>3$ years) had $+97.50 \mathrm{~kg}$ and $+83.60 \mathrm{~kg}$ higher live weight; +59.83 $\mathrm{kg}$ and $+40.65 \mathrm{~kg}$ higher hot carcass weight; and +58.11 $\mathrm{kg}$ and $39.21 \mathrm{~kg}$ higher cold carcass weight compared to very young ( $<2$ years) and young (2-3 years) groups, respectively. Similarly, Bazzoli et al5 reported that young cull cows had lighter carcasses and carcass weight increased with age at slaughter until 5 to 6 years. It is worth noting that, these researchers indicated that young cull cow carcasses received the greatest value and carcass price. They also reported that carcass price of cows ( $>3$ years) seemed to be fixed, whereas carcass value tended to increase up to 5-6 years of age, after which the value decreased. In this respect, economic factors such as carcass prices, prices of valuable cuts, and feed costs should be widely evaluated in order to earn maximum income possible.

Concerning meat production, evaluation of optimum slaughter age plays an important role in achieving maximum net return and profitability. ${ }^{11,12}$ In the present study, young (2-3 years) group showed higher hot carcass dressing $(+2.09 \%$ and $+0.71 \%$, respectively) and cold carcass dressing $(+3.86 \%$ and $+0.77 \%$, respectively) compared to very young ( $<2$ years) and mature ( $>3$ years) groups (Table 2 ). A possible explanation for these results may be related to fatness, since the proportion of fat in carcasses increases and the relative proportion of muscles decreases, as animals become older. ${ }^{13,14}$ These findings are consistent, in part, with those reported by Litwinczuk et $\mathrm{al}^{15}$ who suggested that dressing percentage in heifers was higher com-

Table 2. Least Square Means $( \pm \mathrm{SE})$ obtained for the effect of slaughter age on live weight and carcass traits

\begin{tabular}{lcccc}
\hline \multirow{2}{*}{ Traits } & \multicolumn{3}{c}{ Age Group } & Significance \\
\cline { 2 - 4 } & $\begin{array}{c}\text { Very young } \\
(<2 \text { years })\end{array}$ & $\begin{array}{c}\text { Young } \\
(2-3 \text { years })\end{array}$ & $\begin{array}{c}\text { Mature } \\
(>3 \text { years })\end{array}$ & \\
\hline & & & & \\
Live weight (kg) & $493.60 \pm 12.93^{\mathrm{b}}$ & $507.50 \pm 13.42^{\mathrm{b}}$ & $591.10 \pm 13.32^{\mathrm{a}}$ & $P<0.001$ \\
Hot carcass weight (kg) & $252.48 \pm 6.01^{\mathrm{b}}$ & $271.66 \pm 6.22^{\mathrm{b}}$ & $312.31 \pm 6.17^{\mathrm{a}}$ & $P<0.001$ \\
Hot carcass dressing (\%) & $51.59 \pm 0.46^{\mathrm{b}}$ & $53.68 \pm 0.48^{\mathrm{a}}$ & $52.97 \pm 0.47^{\mathrm{ab}}$ & $P<0.01$ \\
Cold carcass weight (kg) & $245.84 \pm 5.87^{\mathrm{b}}$ & $264.74 \pm 6.07^{\mathrm{b}}$ & $303.95 \pm 6.02^{\mathrm{a}}$ & $P<0.001$ \\
Cold carcass dressing (\%) & $48.46 \pm 0.87^{\mathrm{b}}$ & $52.32 \pm 0.90^{\mathrm{a}}$ & $51.55 \pm 0.89^{\mathrm{ab}}$ & $P<0.01$ \\
Chilling loss (\%) & $2.88 \pm 0.36$ & $3.15 \pm 0.37$ & $2.41 \pm 0.37$ & $\mathrm{NS}$ \\
Bone content (kg) & $55.61 \pm 2.18^{\mathrm{b}}$ & $58.89 \pm 2.35^{\mathrm{ab}}$ & $65.31 \pm 1.96^{\mathrm{a}}$ & $P<0.01$ \\
Bone content percentage (\%) & $20.59 \pm 0.49$ & $21.10 \pm 0.53$ & $20.62 \pm 0.45$ & $\mathrm{NS}$ \\
Total meat yield (kg) & $201.60 \pm 11.61$ & $211.94 \pm 16.56$ & $227.35 \pm 15.32$ & $\mathrm{NS}$ \\
Meat percentage (\%) & $76.28 \pm 1.04$ & $77.14 \pm 1.48$ & $75.48 \pm 1.37$ & $\mathrm{NS}$ \\
Valuable cuts (kg) & $34.66 \pm 2.21$ & $33.21 \pm 3.16$ & $36.63 \pm 2.93$ & NS \\
Percentage of valuable cuts (\%) & $13.17 \pm 0.42$ & $12.17 \pm 0.61$ & $12.19 \pm 0.56$ & NS \\
Processing loss (\%) & $3.06 \pm 0.19$ & $2.95 \pm 0.21$ & $3.16 \pm 0.20$ & NS \\
& & & & \\
\hline
\end{tabular}


pared to cows. Dressing percentage is an important indicator in the evaluation of carcass characteristics and it rose with increasing slaughter weights. Moreover, evaluation of dressing percentage may present indicative results for both meat quantity and quality, because the rise in dressing percentage, as growth proceeds, is a direct result of increasing fatness. ${ }^{16}$ Taken together, present results may be not only useful for further studies, but also for a sustainable and profitable dairy management.

Regarding bone content $(\mathrm{kg})$, pronounced differences were observed among age groups $(\mathrm{P}<0.01)$. Mature group had $+9.70 \mathrm{~kg}$ and $6.42 \mathrm{~kg}$ higher bone content compared to very young and young groups, respectively. It has been assumed that, bone content decreases when carcass weight increases. Although evaluation of bone content may reflect some breed-specific characteristics, it could also be related to differences in carcass weight. ${ }^{17}$ However, this interpretation was not substantiated in this study, because mature cull cows had the highest carcass weights, and they also had the highest bone content. As indicated by Harte and Conniffe, ${ }^{18}$ the percentage yield of bone depends on the degree of fatness of the carcass. The results of the present study may thus be related to the proportions of subcutaneous and intermuscular fat. No significant differences among age groups were observed in terms of chilling loss, bone content percentage, total meat yield, meat percentage, valuable cuts, percentage of valuable cuts, and processing loss (Table 2).

Least square means, shown in Table 3, indicated that live weight and some carcass traits differed significantly by slaughter season at different levels of significance. In this context, cull cows slaughtered in autumn had $+31.97 \mathrm{~kg}$ higher live weight compared to those slaughtered at summer season. On the other hand, hot carcass dressing and cold carcass dressing were significantly higher in summer season $(\mathrm{P}<0.01$ and $\mathrm{P}<0.05$, respectively). Here, it should be noted that there was no significant effect of slaughter season on hot carcass weight and cold carcass weight $(\mathrm{P}>0.05)$. The effect of slaughter season on chilling loss was found to be statistically significant $(\mathrm{P}<0.001)$. Cull cows slaughtered in summer had $1.45 \%$ higher chilling loss compared to cows slaughtered in autumn. On the other hand, these animals exhibited $1.39 \%$ less bone content percentage. In further-processing, autumn season was significantly associated with higher processing loss $(\mathrm{P}<0.001)$. Carcasses of cows which slaughtered in this season had $0.96 \%$ higher processing loss values compared with those slaughtered in summer. There was no association between slaughter season and hot carcass weight, cold carcass weight, and bone content nor was there any association of further-processing traits including total meat yield, meat percentage, valuable cuts, and percentage of valuable cuts with seasons in the present study. Differences in carcass characteristics of the groups based on the seasonal changes are most likely caused by weather conditions. Indeed, climatic variations may directly or indirectly affect red meat production in many ways. The responses of animal to seasonal changes may be dramatic. For instance, these variations can have a direct action upon the animal whereas other indirect actions are related to feeding practices, life cycles of internal and external parasites and survival of microorganisms that cause diseases. ${ }^{19}$ Hence, significant differences in carcass

Table 3. Least Square Means $( \pm \mathrm{SE})$ obtained for the effect of slaughter season on live weight and carcass traits

\begin{tabular}{lcccc}
\hline & \multicolumn{3}{c}{ Age Group } & \\
\cline { 2 - 4 } Traits & $\begin{array}{c}\text { Very young } \\
(<2 \text { years })\end{array}$ & $\begin{array}{c}\text { Young } \\
(2-3 \text { years })\end{array}$ & $\begin{array}{c}\text { Mature } \\
(>3 \text { years })\end{array}$ & Significance \\
\hline & & & & \\
Live weight (kg) & $493.60 \pm 12.93^{\mathrm{b}}$ & $507.50 \pm 13.42^{\mathrm{b}}$ & $591.10 \pm 13.32^{\mathrm{a}}$ & $P<0.001$ \\
Hot carcass weight (kg) & $252.48 \pm 6.01^{\mathrm{b}}$ & $271.66 \pm 6.22^{\mathrm{b}}$ & $312.31 \pm 6.17^{\mathrm{a}}$ & $P<0.001$ \\
Hot carcass dressing (\%) & $51.59 \pm 0.46^{\mathrm{b}}$ & $53.68 \pm 0.48^{\mathrm{a}}$ & $52.97 \pm 0.47^{\mathrm{ab}}$ & $P<0.01$ \\
Cold carcass weight (kg) & $245.84 \pm 5.87^{\mathrm{b}}$ & $264.74 \pm 6.07^{\mathrm{b}}$ & $303.95 \pm 6.02^{\mathrm{a}}$ & $P<0.001$ \\
Cold carcass dressing (\%) & $48.46 \pm 0.87^{\mathrm{b}}$ & $52.32 \pm 0.90^{\mathrm{a}}$ & $51.55 \pm 0.89^{\mathrm{ab}}$ & $P<0.01$ \\
Chilling loss (\%) & $2.88 \pm 0.36$ & $3.15 \pm 0.37$ & $2.41 \pm 0.37$ & NS \\
Bone content (kg) & $55.61 \pm 2.18^{\mathrm{b}}$ & $58.89 \pm 2.35^{\mathrm{ab}}$ & $65.31 \pm 1.96^{\mathrm{a}}$ & $P<0.01$ \\
Bone content percentage (\%) & $20.59 \pm 0.49$ & $21.10 \pm 0.53$ & $20.62 \pm 0.45$ & $\mathrm{NS}$ \\
Total meat yield (kg) & $201.60 \pm 11.61$ & $211.94 \pm 16.56$ & $227.35 \pm 15.32$ & $\mathrm{NS}$ \\
Meat percentage (\%) & $76.28 \pm 1.04$ & $77.14 \pm 1.48$ & $75.48 \pm 1.37$ & NS \\
Valuable cuts (kg)* & $34.66 \pm 2.21$ & $33.21 \pm 3.16$ & $36.63 \pm 2.93$ & NS \\
Percentage of valuable cuts (\%) & $13.17 \pm 0.42$ & $12.17 \pm 0.61$ & $12.19 \pm 0.56$ & NS \\
Processing loss $(\%)$ & $3.06 \pm 0.19$ & $2.95 \pm 0.21$ & $3.16 \pm 0.20$ & NS
\end{tabular}


traits between two seasons may be related to changes in weather conditions.

The finishing of cull cows in the dairy herds can be an important activity to raise the profits of a cattle farm. ${ }^{20}$ Considering the approximately 6.4 million total dairy cattle count in Turkey ${ }^{9}$, the number of cull cows from dairy herds that are eligible to enter the beef supply chain cannot be underestimated. To our knowledge, there are limited studies on the effects of slaughter season on the carcass characteristics of meat derived from cull cows, and therefore, present results may contribute to current applications of culling strategies in dairy management.

\section{Conclusions}

Farmers cull individual cows for multiple reasons and the value of cull cows at slaughter represents an important source of income for dairy farms. Nevertheless, considerable variation in cull cow carcass traits exists. Taken together, extensive carcass assessment of cull cows including both environmental and economic factors may provide useful clues for achieving a profitable dairy management. The current study clearly demonstrated that carcass traits of cull cows were highly influenced by age at slaughter and slaughter season. Cull cows older than three years of age were characterised by higher live weight, carcass weights, and bone content, whereas, cull cows at two to three years of age were characterised by higher carcass dressing values. Concerning slaughter season, autumn was significantly associated with higher live weight, bone content percentage, and processing loss, whereas, summer was associated with higher carcass dressings and chilling loss. The present results could therefore be useful for future studies on carcass traits of dairy cull cows.

\section{References}

1. Shemeis A, Liboriussen T, Andersen BB, Abdallah O. Changes in carcass and meat quality traits of Danish Friesian cull cows with the increase of their age and body condition. Meat Sci. 1994;37:161-167.

2. Bascom S, Young A. A summary of the reasons why farmers cull cows. J Dairy Sci. 1998;81:2299-2305.

3. Rogers G, Van Arendonk J, McDaniel B. Influence of Involuntary Culling on Optimum Culling Rates and Annualized Net Revenue1. J Dairy Sci. 1988;71:34633469.

4. Stelzleni AM, Patten LE, Johnson DD, Calkins CR, Gwartney BL. Benchmarking carcass characteristics and muscles from commercially identified beef and dairy cull cow carcasses for Warner-Bratzler shear force and sensory attributes. J Anim Sci. 2006;85: $2631-2638$.
5. Bazzoli I, De Marchi M, Cecchinato A, Berry D, Bittante $G$. Factors associated with age at slaughter and carcass weight, price, and value of dairy cull cows. J Dairy Sci. 2014;97:1082-1091.

6. Allaire F, Sterwerf H, Ludwick T. Variations in Removal Reasons and Culling Rates with Age for Dairy Females1. J Dairy Sci. 1977;60:254-267.

7. Esslemont R, Kossaibati M. Culling in 50 dairy herds in England. Vet Rec. 1997;140:36-39.

8. McCullough D, DeLorenzo M. Effects of Price and Management Level on Optimal Replacement and Insemination Decisions1. J Dairy Sci. 1996;79: 242-253.

9. Turkish Statistical Institute. Livestock Statistics 2018, www.turkstat.gov.tr (last access: 19 September 2019), 2019.

10. Koch RM, Dikeman ME. Characterization of biological types of cattle. V. Carcass wholesale cut composition. J Anim Sci. 1977; 45:30-42.

11. Aydin R, Yanar M, Diler A, Kocyigit H, Tuzemen N. Effects of different slaughter ages on the fattening performance, slaughter and carcass traits of Brown Swiss and Holstein Friesian young bulls. Indian J Anim Res. 2013;47:10-16.

12. Marti S, Realini C, Bach A, Pérez-Juan M, Devant M. Effect of castration and slaughter age on performance, carcass, and meat quality traits of Holstein calves fed a high-concentrate diet. J Anim Sci. 2013;91:1129-1140.

13. Ustuner H, Yalcintan H, Orman A, Ardicli S, Ekiz B, Gencoglu H, Kandazoglu O. Effects of initial fattening age on carcass characteristics and meat quality in Simmental bulls imported from Austria to Turkey. S Afr J Anim Sci. 2017;47:194-201.

14. Ardicli S, Dincel D, Balci F. Determining The Yields and Percentages of Retail Cuts From Holstein Bull Carcasses Marketed in South Marmara Region of Turkey. Kocatepe Vet J. 2018;11: 223-231.

15. Litwinczuk Z, Barlowska J, Florek M, Tabała K. Slaughter value of heifers, cows and young bulls from commercial beef production in the central-eastern region of Poland. Anim Sci Pap Rep. 2006;24:187-194.

16. Simões JA, Mira J, Lemos J, Mendes I. Dressing percentage and its relationship with some components of the fifth quarter in Portuguese cattle breeds. Livest Prod Sci. 2005;96:157-163.

17. Piedrafita J, Quintanilla R, Sañudo C, Olleta JL, Campo MM, Panea B, Renand G, Turin F, Jabet S, Osoro K, Olivan MC, Noval G, Garica P, Garcia P, Garcia MD, Oliver MA, Gispert M, Serra X, Espejo M, Garcia S, Lopez M, Izquierdo M. Carcass quality of 10 beef cattle breeds of the Southwest of Europe in their typical production systems. Livest Prod Sci. 2003;82:1-13. 
18. Harte F, Conniffe D. Studies on cattle of varying growth potential for beef production: II. Carcass composition and distribution of lean meat, fat and bone. Irish J Agr Res. 1967;6:153-170.

19. Kang SM, Lee IS, Lee SK. Carcass characteristics of Hanwoo (Korean cattle) from different sex conditions, raising altitudes and slaughter seasons. Livest Sci. 2009;123:283-287.

20. Franco D, Bispo E, Gonzalez L, Vazquez JA, Moreno T. Effect of finishing and ageing time on quality attributes of loin from the meat of Holstein-Friesian cull cows. Meat Sci. 2009;83:484-491. 